\title{
Psychoeducation group counselling for emotional intelligence among secondary school female students
}

\author{
Ummur Radhiah Hussin ${ }^{1}$, Zuria Mahmud ${ }^{2}$, Dharatun Nissa Fuad Mohd Karim ${ }^{3}$ \\ ${ }^{123}$ Universiti Kebangsaan Malaysia
}

\begin{tabular}{l}
\hline Article Info \\
\hline Article history: \\
Received Jan $12^{\text {th }}, 2020$ \\
Revised Feb $10^{\text {th }}, 2020$ \\
Accepted Feb $16^{\text {th }}, 2020$ \\
\hline
\end{tabular}

\section{Keyword:}

Secondary school Females group counseling psychoeducation emotional intelligence emotional management

\begin{abstract}
Students who have difficulties understanding and managing their emotions are also potentially challenged in organizing other aspects of their life such as academics performance and peer relationships. This article reports on a psycho-educational intervention for a group of 19 female students (age 15 to 16 years old) at a secondary school to help them improve their knowledge and skills in controlling their emotions in a more effective way. The students were involved in five psychoeducational group counselling sessions, which lasted between 40 to 45 minutes each session. The module for this intervention contained group counselling, creative activities (drawing, balloon blowing) and answering checklists (emotional stability). The emotional stability checklist showed that participants who scored low on anxiety and depression showed good responses and were engaged in the discussion. Meanwhile, students who scored high on anxiety, low self-esteem, and depression were less involved. However, the activities enabled students to know their friends better, enabled students feel more comfortable to share about themselves, able to understand beyond basic emotions and feel more empowered in controlling their emotions. This study supports the use of counseling group psychoeducation activities in providing quality programs for helping adolescents understand
\end{abstract}

(C) 2020 The Authors. Published by IICET

This is an open access article under the CC BY-NC-SA license

(https://creativecommons.org/licenses/by-nc-sa/4.0

\section{Corresponding Author:}

Zuria Mahmud

Universiti Kebangsaan Malaysia

*Corresponding author, e-mail: zuria@ukm.edu.my

\section{Introduction}

Secondary school students are a group of people in an intermediate stage between adolescence and early adulthood, facing a critical stage of transition. At this stage, they experience physical, cognitive, social and emotional developmental changes (Boyd \& Bee, 2012). Changes in roles and responsibilities at home or at school can cause adolescents to feel pressured in adapting to changes at this level. However, uncontrolled behavioral and emotional problems in adolescents do not contribute to academic, social relationships (Ferlis Bullare et al., 2015) and successful adulthood (Pao, 2017).

Management of emotions requires understanding and controlling feelings in oneself and others, preventing from reactive outburst. Goleman (1996) stated that to manage emotions, one needs emotional intelligence. Emotional intelligence involved individual to recognize and evaluate their feelings and people around them for them to respond better to that feeling. Habibah and Noran Fauziah (2002), defines emotional intelligence as a 
flexible, realistic and successful individual in solving problems and controlling oneself in the face of stress. As such, emotional intelligence is seen to be able to influence adolescents' stress.

A study by the National Health and Morbidity Survey of 2017 (Institute for Public Health, 2017) showed that the prevalence of depression among adolescents in Malaysia was $18.3 \%$, anxiety 39.6\% and stress $9.6 \%$. This alarming statistics implicated that the mental health status of adolescents' emotional levels should be of a concern to society. Depression and other mental health issues could be contributed by poor emotional management (Young, Sandman \& Craske, 2019).

Good emotional management is a prerequisite for human capital development. One of the way to manage emotions among adolescents is through a psychoeducational approach in group counseling. Counseling is a process that helps individuals form new dimensions of thinking, behavior, and emotion (Mohd Azhan \& $\mathrm{Ku}$ Suhaila, 2016). In addition, counseling plays a role in helping individuals identify and explore their potential. Whereas psychoeducation is a systematic education of the processes and factors associated with human education (Ahmad, 2013). Therefore, psychoeducational groups play a similar role as counseling and psychotherapy in shaping individuals in a more positive direction. Recent studies such as Mohd Rafidi, Abd. Halim and Saedah (2015) found that group counseling programs can increase the motivation of drug addicts in rehabilitation centers. Similarly, Falco and Bauman (2014) also found that counseling for children of divorced parents is an effective therapy as it provides a mechanism for them to talk about their feelings and experiences thus reducing their negative feeling.

In addition to verbal therapy, counseling interventions involve a variety of media and techniques that help clients express themselves. One of the most creative approaches supported by professionals includes art therapy. Tripathi and Dilawari (2012) define art therapy as a form of projective technique that uses the creative process of art to enhance the physical, mental and emotional well-being of individuals of all ages. This is in line with the study conducted by Zuria et al. (2018) using creative interventions in solving bully problems among female students.

Based on previous studies, creative interventions and counseling can help adolescents improve their capacity to cope with issues and problems encountered. Thus, the emotional management of high school adolescents was conducted using a psycho-educational approach in group counseling. A module has been developed that incorporates various creative approaches to counseling. Therefore, this study aims to help students improve their knowledge and skills in controlling their emotions in a more effective way.

\section{Method}

This study is a case study conducted at a secondary school in Malaysia. The sample comprised 19 female Malay students who are in form four. These students were recommended by the school's counseling unit based on their Depression, Anxiety and Stress Scale (DASS) (Lovibond \& Lovibond, 1995) test score and the Adolescent Coping Skill (ACS) (Frydenberg \& Louis, 1993) questionnaire. DASS test showed that 6 students scored low and medium level stress, 9 students experienced mild levels of anxiety and 4 moderately experienced depression. ACS analysis showed that 15 students had good scores and 4 had moderate and mild scores. The involvement of the students in the group has been approved by the school.

Psychoeducational counseling was conducted for 1 day through 5 sessions namely (1) Getting to Know Yourself and Others, (2) Types of Emotion (3) Emotional Stage (4) Managing Emotions and (5) Termination. The group session was conducted by four postgraduate students in UKM. In the first session (Getting to Know Yourself and Others) students chose something significant to them found around the school area, and then given the opportunity to share about the selected items and why it was meaningful to them. In the second session (Types of Emotion), students were asked to draw their emotional emoji. The researchers focused on group members emotional knowledge to improve participants' sensitivity to their own emotions. Group members were asked to draw their emotional emoji (digital icon for expression of feelings) on a piece of paper. Other members were to guess the presenter's emotions and shared their views on the presenter's emoji. After receiving feedback from each member, the member who drew the emoji explained the actual emotional emoji and shared about the choice of emotion. Then, students discussed the most difficult emotions to manage and how to deal with them.

In the third session (Emotional Stage), students were asked to mark a checklist called Beremosi atau Stabil (Emotional Stability Checklist) by Fadilah Mohamed, Mohd Hasni, Che Som, Mohd Hatta \& Mastura (2016). The checklist has 50 items. The analysis of the findings of the checklist is divided into five categories namely anxiety, guilt, tension, low self-esteem and depression. During the fourth session (Managing Emotions), students went through emotional management simulation through balloon blowing activities. Each member of 
the group was asked to blow the balloon while imagining that each blow is an emotion blown into the balloon. Then, the group members were asked to release the blown balloons gradually, imagining that each emotion could be released one at a time. The session was concluded by members sharing their feelings when releasing the balloon. For the final session (Termination), students were asked to share their experiences from the first session to the last session.

Data for this study was collected qualitatively throughout the five sessions. The researcher recorded in written notes participants' behavioral reactions and oral responses for each session. The researchers notes were analyzed manually to arrive at common themes that represented participants responses.

\section{Results and Discussions}

Each session provided data worth discussing. The focus of the first session was to build rapport among group members. Among the items selected by the participants were leaves (10), flowers (6), a stone, a pen and a cat. Most of those who chose flowers said that flowers symbolizes their characters as being soft, love beauty, and cheerful. Those who chose leaves describe the common themes of fragility and loves nature. One student who chose a few leaves for herself describe that this symbolized her need for the support of family and friends. The student who chose stone described herself as stubborn and hard hearted, while the student who chose cat loved the softness of the cat fur which she said bring her calmness. Through this activity, participants developed a good rapport. This occurs when individuals were given the opportunity to express themselves in groups. They were free to set norms in groups and were free to share anything. This helped reduce embarrassment and build resilience between them as mentioned by Falco and Bauman (2014) who suggest that counseling groups are a good channel for individuals to share their feelings and reduce the negative feelings they experience.

In the emoji drawing session, participants expressed only basic feelings such as happiness, sadness, anger and calmness. However, after the facilitator exposed them to different emotions, they were able to identify beyond basic emotions such as hopelessness, frustation, anxiety, disappointment, blamed, and excitement. One of the most difficult emotions a group member must deal with is hopelessness especially in some of challenging academic subjects. Through group discussion and sharing, the way to overcome despair is to stay positive and to make the failure a challenge to move forward. The improved knowlege about emotional identification is in line with the study of Hamidah Sulaiman, Afandi Sutrisno Tanjung, Nor Faezah Md Khalid, Norsafatul Aznin A. Razak and Nor Hasbuna Salleh (2013) who suggested that school adolescents' emotional intelligence needs to be increased especially in the areas of social skills so they can manage themselves in a challenging environment.

In the third session, students marked the emotional stability checklist. As a result of the checklist, there were group members who scored high on anxiety, low self-esteem, and depression. The participants were able to know deeper their emotional problems. The emotional stability checklist gave them a good sense of how emotional they were. Among the identified emotional problems are depression, low self-esteem, and anxiety. The findings showed that participants were experiencing symptoms of mental health (Mental Health Foundation, 2016). These symptoms should be noted and should not be ignored.

Through the balloon blowing activity, group members identified ways to express emotional burdens in their initial efforts to control them. Students learned to use proper breathing techniques during this activity. Students mentioned they felt relieved and reported they could better control their emotions through the gradual release of balloons while imagining that each emotion could be released one at a time. One student mentioned that "Now I know that emotion should not be released in sudden outburst but I should organize to release my emotions bit by bit". Thus, in the fourth session the participants were given information on effective ways of managing their emotions so they can alleviate their emotional problems. Disclosure of how to manage emotions through counseling in a psycho-educational group is a method that could enhance emotional intelligence and improved coping strategies for emotional problems (Melissa Edora Sanu \& Balan Rathakrishnan, 2019). In addition, research has found that learning breathing techniques can reduce stress (Sellakumar, 2015).

Through the sharing of experiences and insights, each participant felt that the program has a positive impact on them, especially in helping them managed their emotions more effectively. Participants also understood the importance of controlling emotions. One participant said that "I felt fortunate to have joined this activity". Most agreed that "Eventhough at first I thought emotional management is just a simple thing, now I learned that there are ways I can practice to manage my emotions". This finding supports the study of Falco and Bauman (2014) who suggested that sharing feelings in a counseling group is a good therapy to reduce negative emotions. 


\section{Conclusions}

The findings of this study have important implications, especially in counselling. Emotional management through this psycho-educational counselling group has a positive impact on helping adolescents to understand, manage and control their own emotions. The methods of implementation of this approach are clearly stated. However, improvements in timing of activities should be noted so that participants have more time to explore their emotional problems more deeply. Overall, this study supports the use of counselling group psychotherapy activities in providing quality programs for adolescent psychological well-being.

\section{References}

Ahmad, A.B. (2013). Kesan Intervensi Psiko-pendidikan Terhadap Tingkah Laku Murid Sekolah Menengah Oleh Guru Bimbingan dan Kaunseling. Kuala Lumpur: Fakulti Pendidikan, Universiti Malaya.

Boyd, D.R. \& Bee, H.L. (2012). Lifespan development. Boston: Pearson.

Falco, L.D., \& Bauman, S. (2014). Groups work in schools. In Corey. M. S., Corey. G., \& Corey. C (pnyt). Groups: Process and practise, 358. Singapore: Cengage Learning.

Ferlis Bullare@, Bahari, Rosnah Ismail, Lailawati Madlan@ Endalan dan Surianti Lajuma. (2015). Strategi daya tindak remaja sekolah dan hubungannya dengan kemurungan. Jurnal Psikologi Malaysia, 29(1), 21-38.

Frydenberg, E., \& Lewis, R. (1993). Adolescent Coping: Administrator's Manual. Melbourne: ACER. Frydenberg, E., \& Lewis, R. (1993). Adolescent Coping: Administrator's Manual. Melbourne: ACER. Frydenberg, E. \& Lewis, R. (1993). Adolescent Coping: Administrator's Manual. Melbourne: ACER. Goleman, D. (1995). Emotional Intelligence: Why it can matter more than IQ. New York: Bantam Books.

Habibah Elias \& Noran Fauziah Yaakub. 2002. Psikologi personaliti. Kuala Lumpur: Dewan Bahasa \& Pustaka.

Hamidah Sulaiman, Afandi Sutrisno Tanjung, Nor Faezah Md Khalid, Norsafatul Aznin A. Razak \& Nor Hasbuna Salleh. (2013). Kecerdasan emosi dalam meningkatkan keperibadian remaja. Jurnal Kurikulum \& Pengajaran Asia Pasifik, 1(3), 28-33.

Insitute for Public Health (IPH). (2017). National Health and Morbidity Survey 2017 (NHMS 2017): Adolescent Mental Health (DASS 21). Retrieved http://iku.moh.gov.my/images/IKU/Document/REPORT/NHMS2017/pdf.

Lovibond, S.H. \& Lovibond, P.F. (1995). Manual for the Depression Anxiety \& Stress Scales. (2 Ed.) Sydney: Psychology Foundation.

Melissa Edora Sanu \& Balan Rathakrishnan. (2019). Strategi daya tindak sebagai mediator dalam hubungan kecerdasan emosi dan kesejahteraan psikologi pelajar miskin di luar bandar sabah. Journal of Advanced Research in Social and Behavioural Sciences, 14(1), 9-15.

Mental Health Foundation. (2016). Fundamental Facts About Mental Health 2016. Mental Health Foundation: London.

Mohamed, F., Zulkifle, M.H., Omar, C.S., Othman M.H., \& Samsaini, M.. (2016). Modul pengurusan emosi dan stres. Negeri Sembilan: Pusat Kaunseling MAINS.

Mohd Rafidi Jusoh, Abd. Halim Mohd Hussin \& Saedah Abdul Ghani. (2015). Keberkesanan terapi kelompok pendidikan psiko dalam meningkatkan motivasi penagih dadah. Jurnal Antidadah Malaysia, 9(1), 1-18.

Mohd Azhan Mohamed Abdul Kadir \& Ku Suhaila Ku Johari. (2016). Keberkesanan psikopendidikan dalam kaunseling kelompok untuk membendung masalah disiplin murid sekolah rendah islam al-amin. International Seminar on Professional Counselling 2016, 88-94. Sarawak: Penerbitan Universiti Malaysia Sarawak.

Pao, M. (2017). Conceptualization of Success in Young Adulthood. Child and Adolescent Psychiatric Clinics of North America, 26(2), 191-198.

Sellakumar, G. K. (2015). Effect of slow-deep breathing exercise to reduce anxiety among adolescent school students in a selected higher secondary school in Coimbatore, India. Journal of Psychological and Educational Research. 23(1), 54-72.

Tripathi, N. \& Dilawari, K. (2012). Effect of art therapy and counseling on adolescents. Indian Journal of Health and Wellbeing, 3(3), 653-658.

Young, K. S., Sandman, C. F., \& Craske, M. G. (2019). Positive and negative emotion regulation in adolescence: links to anxiety and depression. Brain Sciences. 9(4). 
Zuria Mahmud, Ku Suhaila Ku Johari, Mohd Izwan Mahmud \& Nor Azita Buyong. (2018). Pendekatan Kreatif Menangani Buli dalam Kalangan Pelajar Perempuan di Sekolah Berasrama: Proceedings of the Play Therapy Seminar 2018 (pp. 68-76). Bangi: Fakulti Pendidikan. 